\title{
Research on Sustainable Evaluation of Poverty Alleviation Governance at County Level in China Based on Survey Data of 86 Counties
}

\author{
Zhentao Ma \\ School of Politics and Public Administration, Anyang Normal University, Anyang, China \\ Email: 3157011@163.com
}

How to cite this paper: Ma, Z. T. (2020). Research on Sustainable Evaluation of Poverty Alleviation Governance at County Level in China Based on Survey Data of 86 Counties. Chinese Studies, 9, 83-95. https://doi.org/10.4236/chnstd.2020.94008

Received: October 20, 2020

Accepted: November 16, 2020

Published: November 19, 2020

Copyright ( 2020 by author(s) and Scientific Research Publishing Inc. This work is licensed under the Creative Commons Attribution International License (CC BY 4.0).

http://creativecommons.org/licenses/by/4.0/

(c) (i) Open Access

\begin{abstract}
Taking the sustainable poverty alleviation governance as the research object, the sustainable evaluation system of poverty alleviation and governance is constructed according to the sustainable development level of poverty alleviation governance and the sustainable development ability of poverty alleviation governance. Using field survey data, this paper investigates the sustainable situation of poverty alleviation governance in 86 counties in China, and evaluates the effectiveness of governments and main responsibilities of at all levels of poverty alleviation governance. The study found that the overall sustainable development status of poverty alleviation governance at county level in China is in good condition or trend: in most counties is relatively strong, with an average score of 78.16, which reflects the remarkable results of targeted and precise measures of poverty alleviation. However, one-third of the counties have the secret worry of insufficient sustainable development capacity, and the sustainable aspect of county poverty alleviation governance in Northeast counties is generally weak, which needs to be focused on. In the post-poverty alleviation stage, we should start with the system construction, continuously improve the system and mechanism, and enhance the endogenous development ability of the poverty alleviation groups, so as to put forward countermeasures and suggestions.
\end{abstract}

\section{Keywords}

Poverty Alleviation and Governance, Sustainable Livelihoods, Sustainable Development Level, Sustainable Development Capacity

\section{Introduction}

China's poverty alleviation work has made great achievements in recent years. 
From 1978 to the end of 2019, China's rural absolute poverty population decreased from 770 million to 5.51 million, and the incidence of poverty dropped from $97.5 \%$ to $0.6 \%$, but its complexity and difficulty are self-evident, and it is impossible to achieve once and for all. As poverty alleviation in an all-round way enters the final stage, the primary absolute poverty that has plagued rural areas for a long time has basically disappeared, and more problems such as the lack of stable anti-poverty capacity, and the phenomenon of returning to poverty caused by disasters, diseases, education, marriage and housing will exist for a long time, and poverty is entering "a new stage of transitional secondary poverty and relative poverty" (Li \& Xu, 2018). This means that the focus of China's poverty alleviation task will shift from eliminating absolute poverty to solving relative poverty. A well-off society in an all-round way does not mean that the poverty problem has been solved. The relative poverty problem has replaced the absolute poverty problem, and presents a multidimensional and urban-rural development problem. Especially for the majority of poverty-stricken households, it is still facing the risk of returning to poverty. So, how to define and measure poverty alleviation sustainability? From what aspects to propose a long-term mechanism to solve this problem? This puts forward higher requirements for the sustainability of poverty alleviation governance.

Sustainable poverty alleviation governance, that is, to maintain the long-term stability of the effect of poverty alleviation and poverty alleviation. The definition of sustainable development includes the original meaning of sustainable development, that is to say, the governance of poverty should reflect the nature of development, to achieve efficient and equitable human and financial investment, intra-and inter-generational equity; to achieve coordinated economic, social and environmental development, and to coordinate poverty alleviation policies with other policies, the coordination between the poor Group and the nonpoor Group, and the exploration of effective anti-poverty institutional mechanisms, models and ways to achieve, in order to consolidate the results of poverty eradication.

Poverty alleviation governance is not a set of rules, regulations and an activity, but a process, and ultimately it should be presented with the corresponding results. Especially for the construction of evaluation system, itself is the embodiment of result-oriented. This study focuses on the realization of intra-generational equity and sustainable poverty alleviation governance at the county level, with the help of the sustainable livelihood framework of the United Nations Development Conference, namely human capital, natural capital, physical capital, financial capital and social (assistance) capital, the main object of sustainable poverty alleviation governance is defined as the stock and increment of livelihood capital. Among them, the stock corresponds to the level of sustainable development, and the increment corresponds to the capacity of sustainable development, so as to build a sustainable evaluation system of poverty alleviation governance, and evaluate the sustainable situation of which in 86 counties of the country. 


\section{Literature Review}

There is a long history of concern about poverty sustainability. The British Chronic Poverty Research Centre (CPRC) pointed out that even if the poor living on the absolute poverty line or below are out of the poverty line, they are very likely to return to poverty, while ordinary households who are not poor may fall into the poverty line. They call this phenomenon "poverty". In recent years, the global poverty alleviation and development work is not optimistic. Thanks to China's poverty eradication achievements, the number of poverty in East Asia has decreased significantly, but the number of absolute poverty in sub Saharan Africa has increased significantly. Apart from East Asia (or China), the rest of the world has not achieved much.

The sustainable evaluation of poverty alleviation is also not a new topic. Some international organizations and research institutes have made explorations. Examples include the livelihood analysis framework of the United Nations Development Programme (UNDP), the farmers' livelihood security framework of Cooperative for American Relief Everywhere (CARE), and the sustainable livelihood analysis framework of the British Department for International Development (DFID). Alkire \& Foster (2008) studied the performance of poverty governance from the aspects of evaluation indicator system and evaluation method, and established multidimensional poverty measurement method with Foster, which was generally accepted and adopted. In the aspect of poverty alleviation and poverty alleviation evaluation research in China, the indicator system is constructed by using analytical hierarchy process (AHP), principal component analysis, expert investigation weight method (Delphi method) and other subjective and objective weighting methods, which has formed abundant achievements. Such as, the first is comprehensive research, such as the evaluation system of targeted Poverty Alleviation (Wang, 2017, 2018; Shi \& Li, 2018); the research on the measurement of farmers' sustainable livelihood level (Wang \& Wang, 2018; Wang et al., 2019; Yang et al., 2017); the second is special research, such as the research on the performance evaluation of poverty alleviation and development projects, the performance audit of poverty alleviation funds and the construction of evaluation index system (Gao \& Wang, 2014; Sun \& Chen, 2015; Qian et al., 2018; Ji \& Wu, 2018); third, research in specific fields, such as the performance of poverty alleviation in tourism and other industries (Wang et al., 2018; Zhang, 2018; Wu, 2017), and educational poverty alleviation performance (Zhang \& Shi, 2018).

From a practical perspective, the current poverty assessment in China mainly examines the situation of poverty reduction in poor counties and the return of the poor to poverty, the incidence of poverty, the rate of wrong return of the poverty-stricken population, the rate of missing assessment of the poverty-stricken population and the rate of acceptance by the general public. These indicators have clear target standards, and the number and scope are limited, for example, the incidence of comprehensive poverty in counties and villages, the rate of wrong return of the poverty-stricken population, the rate of missing evaluation of po- 
verty is more than $2 \%$ (the western region is more than $3 \%$ ), and the rate of acceptance of the general public is less than $90 \%$, which is not up to standard. On the whole, there is no systematic evaluation for poverty alleviation governance and the evaluation of sustainable development through poverty withdrawal lacks pertinence. In addition, the inadequate disclosure of evaluation results information restricts academic research to a certain extent.

To sum up, the research and practice of sustainable evaluation of poverty alleviation governance in China lag behind the process of poverty alleviation, and there are deficiencies in the design of key indicators or variables, resulting in the difficulty of the target take measurements, inconsistent standard. Besides, in the construction of monitoring system, due to the lack of a big data platform covering multi-industries and multi-fields, the necessary data and methods are not stored, especially as the front-line battlefield of poverty alleviation, the evaluation of county poverty alleviation governance is relatively weak. In view of this, this study attempts to build a sustainable evaluation indicator system of poverty alleviation governance, with the help of survey data, to carry out empirical study on the sustainable situation of poverty alleviation governance in 86 counties.

\section{Evaluation System}

The sustainable evaluation of poverty alleviation governance is based on the sustainable livelihood framework, and the indicators connected to the sustainable poverty alleviation of farmers are selected to carry out related work. The selection of indicators focuses on reflecting the law of poverty alleviation, selecting the typical, key and comparable factors concerned by farmers, and ensuring the coordination, cohesion and organic combination of indicators. The number of indicators is moderate, concise, non-repeated and non-omitted, and independent of each other at the same level, reflecting commonalities. The unified caliber among farmers, rural areas and regions ensures that it can be comparable at different times, in different regions, among different farmers and rural areas. At the same time, the indicators selection not only consider the current situation of poverty alleviation, but also base on the relative poverty evaluation after 2020 .

The sustainable evaluation indicators system of poverty alleviation governance is set as one Level 1 indicator, that is, the sustainable indicator of poverty alleviation governance; two Level 2 indicators, namely, the sustainable development level indicator of poverty alleviation and governance, and the sustainable development ability indicator of poverty alleviation and governance; five Level 3 indicators, namely, natural capital, material capital, financial capital, human capital and supporting capital. Level 4 specific indicators are selected, focusing on the second-level indicators and third-level indicators, and nearly 100 indicators related to the sustainability of poverty alleviation governance are obtained from relevant literature abroad, field research in villages and households, and interviews with front-line poverty alleviation cadres in counties and villages. After screening, merging and optimization, the final specific indicators of sustainable poverty alleviation and governance include 14 (Table 1), These indicators are 
per capita cultivated land area, per capita forest land area, topography, satisfaction with housing improvement, drinking water supply mode, travel time to county town, per capita net income of family year, net income of production and operation and the proportion of wage income to family net income, the number of family labor force, the proportion of non-labor force population and the loss of labor force. Number of family school-age children receiving nine-year compulsory education, village-level collective economic income, number of village professional cooperative organizations in normal operation and village professional cooperative and the proportion of farmers covered by village professional cooperative organizations. These selected indicators, some of which need to be investigated in villages and some need to be further calculated and processed, are generally available and operable, and take into account the characteristics of the whole country, especially the central and Western provinces with concentrated poverty areas.

Table 1. Sustainable poverty alleviation indicator system.

\begin{tabular}{|c|c|c|c|c|c|}
\hline $\begin{array}{l}\text { Level } 1 \\
\text { Indicator }\end{array}$ & $\begin{array}{l}\text { Level } 2 \\
\text { Indicator }\end{array}$ & $\begin{array}{l}\text { Level } 3 \\
\text { Indicator }\end{array}$ & $\begin{array}{l}\text { Level } 4 \\
\text { Indicator }\end{array}$ & $\begin{array}{l}\text { Units and } \\
\text { Assignment }\end{array}$ & Attribute \\
\hline \multirow{14}{*}{$\begin{array}{l}\text { Pro-poor } \\
\text { governance } \\
\text { sustainability } \\
\text { indicator a }\end{array}$} & \multirow{8}{*}{$\begin{array}{l}\text { Level of } \\
\text { sustainable } \\
\text { development } \\
\text { indicator B1 }\end{array}$} & \multirow{3}{*}{$\begin{array}{l}\text { Natural } \\
\text { capital C1 }\end{array}$} & Per capita cultivated land area D1 & Mu per person & $\begin{array}{l}\text { Positive } \\
\text { Indicator }\end{array}$ \\
\hline & & & Forestland area per capita D2 & $\mathrm{Mu}$ per person & $\begin{array}{l}\text { Positive } \\
\text { Indicator }\end{array}$ \\
\hline & & & Terrain D3 & $\begin{array}{l}\text { Mountain area }=1 ; \text { Hills }=2 ; \\
\text { Plains and others }=3\end{array}$ & $\begin{array}{l}\text { Positive } \\
\text { Indicator }\end{array}$ \\
\hline & & \multirow{3}{*}{$\begin{array}{l}\text { Physical } \\
\text { capital C2 }\end{array}$} & $\begin{array}{l}\text { Satisfaction with improvement of } \\
\text { housing conditions D4 }\end{array}$ & $\begin{array}{l}\text { Very satisfied }=5 ; \text { Relatively satisfied }=4 ; \\
\text { Average }=3 ; \text { not satisfied }=2 ; \\
\text { Very Dissatisfied }=1\end{array}$ & $\begin{array}{l}\text { Positive } \\
\text { Indicator }\end{array}$ \\
\hline & & & Drinking water supply mode D5 & $\begin{array}{l}\text { Tap water }=4 \text {; Centralized water supply } \\
\text { facilities }=3 \text {; Decentralized autonomous } \\
\text { water extraction }=2 \text {; Decentralized } \\
\text { autonomous water storage (water cellar) }=1\end{array}$ & $\begin{array}{l}\text { Positive } \\
\text { Indicator }\end{array}$ \\
\hline & & & Time to the county town by car D6 & Hour & $\begin{array}{l}\text { Inverse } \\
\text { Indicator }\end{array}$ \\
\hline & & \multirow{2}{*}{$\begin{array}{l}\text { Financial } \\
\text { capital C3 }\end{array}$} & $\begin{array}{l}\text { Annual per capita net income of } \\
\text { households D7 }\end{array}$ & Yuan & $\begin{array}{l}\text { Positive } \\
\text { Indicator }\end{array}$ \\
\hline & & & $\begin{array}{l}\text { Proportion of net income from production } \\
\text { and operation and wage income to net } \\
\text { household income D8 }\end{array}$ & Percent & $\begin{array}{l}\text { Positive } \\
\text { Indicator }\end{array}$ \\
\hline & \multirow{6}{*}{$\begin{array}{l}\text { Indicator of } \\
\text { sustainable } \\
\text { development } \\
\text { capacity B2 }\end{array}$} & \multirow{4}{*}{$\begin{array}{l}\text { Human } \\
\text { capital C4 }\end{array}$} & Number of household labour force D9 & Number & $\begin{array}{l}\text { Positive } \\
\text { Indicator }\end{array}$ \\
\hline & & & $\begin{array}{l}\text { Proportion of population not in the labor } \\
\text { force and population without labor force } \\
\text { D10 }\end{array}$ & $\begin{array}{l}\text { Percent } \\
\text { Ratio of non-working-age population, disabled } \\
\text { population and total household population }\end{array}$ & $\begin{array}{l}\text { Inverse } \\
\text { Indicator }\end{array}$ \\
\hline & & & $\begin{array}{l}\text { Number of family age children receiving } \\
\text { nine years of compulsory education D11 }\end{array}$ & Number & $\begin{array}{l}\text { Positive } \\
\text { Indicator }\end{array}$ \\
\hline & & & $\begin{array}{l}\text { Village-level collective economic income } \\
\text { D12 }\end{array}$ & Ten Thousand yuan & $\begin{array}{l}\text { Positive } \\
\text { Indicator }\end{array}$ \\
\hline & & \multirow[t]{2}{*}{$\begin{array}{l}\text { Supporting } \\
\text { Capital C5 }\end{array}$} & \multicolumn{2}{|c|}{$\begin{array}{l}\text { Number of functioning village professional } \\
\text { cooperative organizations D13 }\end{array}$} & $\begin{array}{l}\text { Positive } \\
\text { Indicator }\end{array}$ \\
\hline & & & $\begin{array}{l}\text { Proportion of farmers covered by village } \\
\text { professional cooperative organizations D14 }\end{array}$ & ${ }_{4}$ Percent & $\begin{array}{l}\text { Positive } \\
\text { Indicator }\end{array}$ \\
\hline
\end{tabular}

Data source: self made by author. 
After that, the method of combining AHP and Delphi method is used to give weights to all levels of indicators. Firstly, the judgment matrix was constructed, and 20 university researchers and front-line poverty alleviation cadres who had been engaged in rural poverty alleviation research for many years were invited to conduct a questionnaire survey to score the importance of the four-level indicators of the sustainability evaluation system of poverty alleviation governance, and the judgment matrix was constructed. Secondly, the hierarchical single sorting and its consistency test are carried out to avoid the large deviation caused by the accumulation of deviation that may occur in a certain data. Thirdly, the total level of sorting and its consistency test. From the highest level to the lowest level, the relative importance of all factors in a given level is calculated. After the individual weight of each indicator is calculated, the comprehensive weight of the four indicators is calculated. Finally, the weight list of the sustainable indicator of poverty alleviation governance is obtained (Table 2).

Table 2. Weight table of sustainable evaluation indicator system for poverty alleviation and governance.

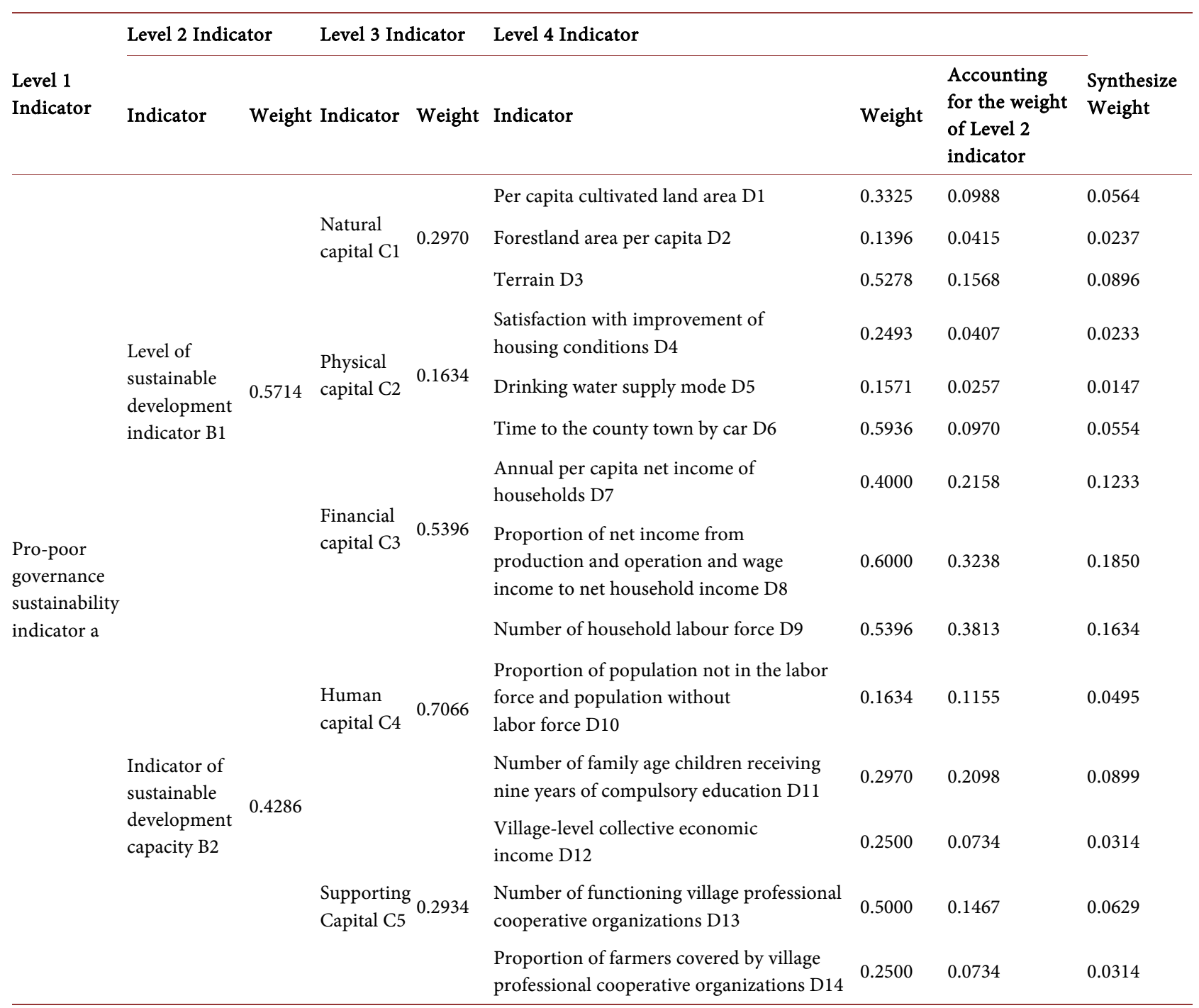

Data source: the author made it according to Delphi method. 


\section{Empirical Analysis}

From 2018 to 2019, the author partially participated in the field monitoring and investigation of poverty alleviation effect carried out by a university project team entrusted by the National Poverty Alleviation Office in Beijing. That investigation fully considered the incidence of poverty at the county and village levels, the size of the poor population, the representativeness of the county in the province and other factors, selected 86 counties in China's 10,487 of households out of poverty conducting a household survey, which is widely geographical coverage and widely range of county and village types, large number of samples, and strong representativeness. The sample covers the eastern, central and western regions, including 50 poverty-stricken counties at the national level, 8 poverty-stricken counties at the provincial level and 28 non-poverty-stricken counties, accounting for $58 \%, 9 \%$ and $33 \%$ of the total sample, respectively, of which 49 counties belong to the concentrated poverty-stricken areas and 8 counties belong to the "three districts and three states" deep poverty-stricken areas, with strong representativeness as a whole.

According to the sustainable evaluation indicator system of poverty alleviation governance, the data of 86 counties are calculated, and the variable values are obtained; then the fuzzy membership function method is applied to the dimensionless processing of the data to get the standardized value (detailed process and results omitted). According to the determined weight values of sustainable indicators for poverty alleviation and governance, the values of various livelihood capital, sustainable development level indicators and sustainable development capacity indicators are calculated respectively, and the sustainable indicators for poverty alleviation and governance are summarized (the result are shown in Table 3), and the corresponding scores are preliminarily analyzed to obtain the level 1 indicator, the level 2 indicatorsand the average value, maximum value and minimum value of five livelihood capitals (Table 4).

Table 3. Sustainable index scores of poverty alleviation and governance in 386 counties.

\begin{tabular}{|c|c|c|c|c|c|c|c|c|c|}
\hline Province & County & $\begin{array}{c}\text { Natural } \\
\text { capital }\end{array}$ & $\begin{array}{c}\text { Material } \\
\text { capital }\end{array}$ & $\begin{array}{c}\text { Financial } \\
\text { Capital }\end{array}$ & $\begin{array}{c}\text { Human } \\
\text { capital }\end{array}$ & $\begin{array}{c}\text { Help } \\
\text { capital }\end{array}$ & $\begin{array}{c}\text { Sustainable } \\
\text { Development } \\
\text { Level }\end{array}$ & $\begin{array}{c}\text { Sustainable } \\
\text { Development } \\
\text { Capacity }\end{array}$ & $\begin{array}{c}\text { Sustainability } \\
\text { pro-poor } \\
\text { governance }\end{array}$ \\
\hline Ningxia & Helan County & 24.17 & 14.03 & 46.16 & 61.26 & 23.37 & 84.36 & 84.63 & 84.48 \\
\hline Guangxi & Gui Ping city & 21.06 & 13.56 & 51.32 & 62.57 & 18.88 & 85.93 & 81.45 & 84.01 \\
\hline Anhui & Taihu County & 20.85 & 14.24 & 52.36 & 58.02 & 19.95 & 87.44 & 77.97 & 83.37 \\
\hline Guangxi & Pinggui district & 18.79 & 13.24 & 49.22 & 66.27 & 19.32 & 81.25 & 85.59 & 83.12 \\
\hline Anhui & Wangjiang County & 22.02 & 14.71 & 51.16 & 56.28 & 20.17 & 87.89 & 76.45 & 82.97 \\
\hline Guangxi & Teng County & 19.55 & 12.94 & 51.82 & 62.31 & 18.41 & 84.31 & 80.72 & 82.77 \\
\hline Guangxi & Bobai County & 19.40 & 13.53 & 49.90 & 61.98 & 20.50 & 82.83 & 82.48 & 82.68 \\
\hline Hainan & Tunchang County & 21.79 & 14.44 & 49.78 & 57.58 & 20.48 & 86.01 & 78.06 & 82.59 \\
\hline Henan & Ruyang County & 21.06 & 14.49 & 48.55 & 60.71 & 19.76 & 84.10 & 80.47 & 82.54 \\
\hline Hainan & Ding'an County & 21.54 & 13.74 & 49.88 & 58.97 & 19.38 & 85.17 & 78.35 & 82.24 \\
\hline
\end{tabular}


Continued

\begin{tabular}{|c|c|c|c|c|c|c|c|c|c|}
\hline Guangxi & Pingnan County & 19.93 & 12.71 & 51.91 & 59.82 & 19.31 & 84.55 & 79.13 & 82.22 \\
\hline Guangxi & Lingshan County & 20.24 & 12.63 & 51.30 & 60.38 & 18.41 & 84.17 & 78.79 & 81.85 \\
\hline Gansu & Qingshui County & 20.60 & 14.11 & 46.63 & 60.20 & 21.86 & 81.34 & 82.06 & 81.65 \\
\hline Gui Zhou & Qi Xing Guan Distict & 19.40 & 13.75 & 46.17 & 64.99 & 19.67 & 79.32 & 84.66 & 81.61 \\
\hline Yunan & Kaiyuan city & 18.88 & 13.38 & 50.64 & 60.88 & 18.50 & 82.91 & 79.38 & 81.39 \\
\hline Gansu & Longxi County & 19.64 & 13.86 & 48.13 & 59.54 & 20.13 & 81.63 & 79.67 & 80.79 \\
\hline Gui Zhou & Jinping County & 19.55 & 13.85 & 49.63 & 56.73 & 21.07 & 83.03 & 77.81 & 80.78 \\
\hline Ningxia & Ling Wu city & 22.26 & 13.73 & 44.89 & 60.28 & 20.24 & 80.88 & 80.51 & 80.72 \\
\hline Szechwan & Ganluo County & 18.25 & 12.80 & 47.14 & 65.22 & 18.76 & 78.19 & 83.98 & 80.68 \\
\hline Fujian & Xiapu County & 20.62 & 14.05 & 51.97 & 54.14 & 18.60 & 86.64 & 72.74 & 80.66 \\
\hline Fujian & Shouning County & 20.24 & 14.23 & 48.71 & 56.63 & 20.67 & 83.17 & 77.30 & 80.65 \\
\hline Hunan & Shaoyang County & 21.23 & 13.74 & 48.73 & 58.09 & 18.32 & 83.70 & 76.42 & 80.57 \\
\hline Gui Zhou & Sinan County & 18.72 & 13.26 & 50.06 & 58.37 & 19.94 & 82.04 & 78.31 & 80.44 \\
\hline Henan & Lu Shan County & 19.44 & 13.16 & 48.60 & 59.48 & 19.61 & 81.20 & 79.09 & 80.29 \\
\hline Jiangxi & Ji'an County & 19.88 & 13.05 & 49.51 & 56.98 & 20.06 & 82.44 & 77.05 & 80.12 \\
\hline Gansu & Maiji district & 18.34 & 13.38 & 47.03 & 60.30 & 21.49 & 78.75 & 81.78 & 80.05 \\
\hline Hubei & Qichun County & 21.14 & 14.28 & 48.70 & 54.54 & 19.91 & 84.12 & 74.45 & 79.96 \\
\hline Anhui & Linquan County & 24.27 & 13.73 & 45.14 & 52.47 & 22.92 & 83.13 & 75.39 & 79.80 \\
\hline Xinjiang & Luopu County & 22.06 & 14.62 & 45.92 & 57.37 & 18.36 & 82.60 & 75.74 & 79.65 \\
\hline Szechwan & Xuyong County & 19.65 & 12.86 & 45.98 & 62.68 & 18.48 & 78.48 & 81.16 & 79.63 \\
\hline Henan & Xin An County & 20.69 & 14.36 & 46.59 & 57.21 & 19.07 & 81.64 & 76.28 & 79.33 \\
\hline Gui Zhou & Zhijin County & 18.23 & 13.10 & 45.87 & 61.75 & 20.10 & 77.20 & 81.84 & 79.20 \\
\hline Jiangxi & Ganxian district & 20.52 & 13.64 & 46.58 & 58.12 & 19.01 & 80.73 & 77.13 & 79.18 \\
\hline Gui Zhou & Luodian County & 18.87 & 12.95 & 46.75 & 60.16 & 19.83 & 78.57 & 79.99 & 79.18 \\
\hline Gansu & Anding district & 20.26 & 13.19 & 45.88 & 58.82 & 20.03 & 79.33 & 78.85 & 79.12 \\
\hline Shaanxi & Yang County & 20.59 & 14.00 & 46.32 & 56.39 & 20.34 & 80.91 & 76.73 & 79.11 \\
\hline Hunan & Longhui County & 20.61 & 13.49 & 46.90 & 57.94 & 18.64 & 80.99 & 76.59 & 79.10 \\
\hline Szechwan & Gu Lin County & 18.34 & 12.44 & 46.32 & 61.56 & 19.98 & 77.09 & 81.54 & 79.00 \\
\hline Yunan & $\begin{array}{c}\text { Lancang Lahu } \\
\text { Autonomous County }\end{array}$ & 19.44 & 12.59 & 47.40 & 60.22 & 18.17 & 79.43 & 78.39 & 78.98 \\
\hline Szechwan & Xide County & 18.55 & 12.69 & 45.69 & 63.75 & 17.69 & 76.93 & 81.44 & 78.87 \\
\hline Yunan & $\begin{array}{l}\text { Hani Autonomous } \\
\text { County of Mojiang }\end{array}$ & 19.29 & 11.48 & 46.15 & 61.12 & 20.27 & 76.91 & 81.39 & 78.83 \\
\hline Gui Zhou & Li Ping County & 18.25 & 12.42 & 46.58 & 60.56 & 20.26 & 77.26 & 80.82 & 78.79 \\
\hline Yunan & Meng Zi city & 18.52 & 13.19 & 46.44 & 60.34 & 18.85 & 78.15 & 79.19 & 78.59 \\
\hline Shandong & Juancheng County & 24.41 & 13.92 & 42.52 & 51.12 & 24.35 & 80.85 & 75.47 & 78.54 \\
\hline Jiangxi & Xin Feng County & 20.44 & 14.18 & 48.41 & 53.14 & 19.43 & 83.02 & 72.58 & 78.53 \\
\hline $\begin{array}{l}\text { Gansu } \\
\text { province }\end{array}$ & Jingyuan County & 18.97 & 11.01 & 45.36 & 59.57 & 22.47 & 75.34 & 82.05 & 78.22 \\
\hline Hubei & Jian Shi County & 18.50 & 13.90 & 46.92 & 55.95 & 20.81 & 79.32 & 76.76 & 78.22 \\
\hline Xinjiang & Yingjisha County & 18.19 & 13.77 & 45.93 & 58.36 & 20.11 & 77.89 & 78.47 & 78.14 \\
\hline Hunan & Lianyuan city & 19.48 & 13.91 & 47.84 & 54.66 & 19.19 & 81.23 & 73.85 & 78.05 \\
\hline
\end{tabular}




\section{Continued}

\begin{tabular}{|c|c|c|c|c|c|c|c|c|c|}
\hline Hunan & Baojing County & 18.50 & 13.40 & 46.56 & 57.45 & 19.83 & 78.46 & 77.28 & 77.95 \\
\hline Shandong & Dong Ming County & 24.50 & 14.15 & 44.65 & 52.13 & 18.57 & 83.30 & 70.71 & 77.88 \\
\hline Hubei & Enshi city & 18.61 & 12.90 & 46.73 & 54.80 & 22.33 & 78.23 & 77.13 & 77.76 \\
\hline Yunan & Xuanwei City & 18.35 & 12.73 & 45.98 & 58.80 & 19.75 & 77.07 & 78.55 & 77.71 \\
\hline Jiangxi & Feng Cheng city & 21.34 & 13.63 & 46.55 & 53.47 & 19.14 & 81.52 & 72.60 & 77.69 \\
\hline Fujian & Zhang Ping city & 20.58 & 13.28 & 47.40 & 53.85 & 19.07 & 81.25 & 72.91 & 77.67 \\
\hline Yunan & Dongchuan district & 18.51 & 12.68 & 46.40 & 55.83 & 21.73 & 77.58 & 77.56 & 77.57 \\
\hline Shanxi & Hunyuan County & 20.57 & 14.63 & 43.30 & 55.34 & 20.97 & 78.50 & 76.30 & 77.56 \\
\hline Shanxi & Shi Lou County & 21.75 & 14.22 & 45.77 & 50.59 & 20.55 & 81.74 & 71.14 & 77.18 \\
\hline Qinghai & Huangzhong County & 18.22 & 14.16 & 47.37 & 54.93 & 18.80 & 79.75 & 73.73 & 77.16 \\
\hline Shaanxi & Shanyang County & 18.54 & 13.87 & 44.93 & 56.40 & 20.09 & 77.35 & 76.49 & 76.98 \\
\hline Chongqing & Wulong district & 19.17 & 13.12 & 47.40 & 54.14 & 18.85 & 79.69 & 72.98 & 76.80 \\
\hline Shaanxi & Xixiang County & 19.12 & 11.44 & 46.45 & 56.35 & 19.55 & 77.00 & 75.90 & 76.53 \\
\hline Shaanxi & Shangzhou district & 18.83 & 13.62 & 44.44 & 56.58 & 19.36 & 76.89 & 75.94 & 76.48 \\
\hline Hubei & Yun Yang Distict & 19.94 & 12.82 & 45.51 & 53.53 & 20.24 & 78.27 & 73.77 & 76.34 \\
\hline Hebei & Longhua County & 20.13 & 13.36 & 44.31 & 54.88 & 19.34 & 77.80 & 74.22 & 76.26 \\
\hline Shanxi & Jiaokou County & 20.83 & 14.25 & 45.59 & 50.10 & 20.12 & 80.67 & 70.22 & 76.17 \\
\hline Heilongjiang & Qing Gang County & 24.68 & 13.83 & 42.07 & 48.19 & 21.70 & 80.58 & 69.89 & 75.99 \\
\hline $\begin{array}{c}\text { Inner } \\
\text { Mongolia }\end{array}$ & Balin Right Banner & 25.58 & 13.59 & 40.87 & 49.01 & 20.84 & 80.04 & 69.84 & 75.66 \\
\hline Shandong & Dongping County & 21.97 & 14.69 & 42.18 & 49.44 & 21.17 & 78.84 & 70.61 & 75.30 \\
\hline Tibet & Nanmulin County & 18.33 & 10.46 & 40.70 & 64.81 & 17.98 & 69.50 & 82.79 & 75.21 \\
\hline Liaoning & Zhang Wu County & 24.30 & 14.38 & 40.52 & 47.84 & 21.52 & 79.20 & 69.35 & 74.97 \\
\hline Szechwan & Meigu County & 18.51 & 13.89 & 39.90 & 59.00 & 18.73 & 72.30 & 77.72 & 74.63 \\
\hline Henan & Nanzhao County & 20.74 & 13.83 & 43.08 & 51.30 & 19.12 & 77.65 & 70.41 & 74.54 \\
\hline Anhui & Taihe County & 24.35 & 13.66 & 41.48 & 45.95 & 21.86 & 79.49 & 67.81 & 74.47 \\
\hline Liaoning & $\begin{array}{c}\text { Fuxin Mongolian } \\
\text { Autonomous County }\end{array}$ & 23.46 & 13.70 & 40.26 & 47.36 & 22.32 & 77.42 & 69.69 & 74.09 \\
\hline Szechwan & Yuexi County & 18.06 & 15.34 & 44.86 & 49.86 & 17.92 & 78.25 & 67.78 & 73.75 \\
\hline Hebei & $\begin{array}{l}\text { Weichang Manchu } \\
\text { and Mongolian } \\
\text { Autonomous County }\end{array}$ & 19.79 & 13.47 & 42.53 & 51.88 & 19.10 & 75.78 & 70.98 & 73.72 \\
\hline Qinghai & Ledu district & 19.38 & 13.83 & 40.71 & 55.30 & 18.09 & 73.92 & 73.39 & 73.69 \\
\hline Fujian & Zhao'an County & 19.49 & 13.55 & 41.71 & 50.58 & 20.73 & 74.75 & 71.31 & 73.27 \\
\hline Liaoning & Jian Chang County & 19.14 & 14.28 & 43.87 & 48.39 & 19.47 & 77.30 & 67.86 & 73.24 \\
\hline Chongqing & Qijiang district & 19.13 & 12.33 & 41.72 & 52.25 & 20.14 & 73.18 & 72.40 & 72.84 \\
\hline Shanxi & Ningwu County & 18.80 & 13.02 & 41.29 & 53.70 & 18.27 & 73.10 & 71.98 & 72.62 \\
\hline Jilin & Gongzhuling City & 25.28 & 13.26 & 39.44 & 43.15 & 18.29 & 77.99 & 61.45 & 70.87 \\
\hline Jilin & $\begin{array}{c}\text { Yitong Manchu } \\
\text { Autonomous County }\end{array}$ & 22.23 & 14.36 & 38.47 & 44.14 & 19.90 & 75.05 & 64.05 & 70.32 \\
\hline $\begin{array}{c}\text { Inner } \\
\text { Mongolia }\end{array}$ & Balin Left Banner & 19.57 & 13.81 & 40.17 & 46.78 & 18.84 & 73.56 & 65.62 & 70.14 \\
\hline Heilongjiang & Beilin district & 25.55 & 13.65 & 35.06 & 43.23 & 19.21 & 74.26 & 62.44 & 69.18 \\
\hline
\end{tabular}

Data source: self made by author. 
Table 4. Mean value, maximum value and minimum value of sustainable indicators of poverty alleviation governance in 386 counties.

\begin{tabular}{|c|c|c|c|c|c|c|c|c|}
\hline Variable Name & $\begin{array}{c}\text { Natural } \\
\text { capital }\end{array}$ & $\begin{array}{c}\text { Material } \\
\text { capital }\end{array}$ & $\begin{array}{c}\text { Financial } \\
\text { Capital }\end{array}$ & $\begin{array}{l}\text { Human } \\
\text { capital }\end{array}$ & $\begin{array}{c}\text { Supporting } \\
\text { capital }\end{array}$ & $\begin{array}{c}\text { Sustainable } \\
\text { Development } \\
\text { Level Indicator }\end{array}$ & $\begin{array}{c}\text { Indicator of } \\
\text { Sustainable } \\
\text { Development } \\
\text { Capacity }\end{array}$ & $\begin{array}{c}\text { Sustainability } \\
\text { indicator for } \\
\text { pro-poor } \\
\text { governance }\end{array}$ \\
\hline Average Value & 20.38 & 13.51 & 45.90 & 56.13 & 19.87 & 79.79 & 76.00 & 78.16 \\
\hline Maximum Value & 25.58 & 15.34 & 52.36 & 66.27 & 24.35 & 87.89 & 85.59 & 84.48 \\
\hline Minimum Value & 18.06 & 10.46 & 35.06 & 43.15 & 17.69 & 69.50 & 61.45 & 69.18 \\
\hline
\end{tabular}

Data source: self made by author.

According to the calculation, the average sustainable indicator of poverty alleviation and governance in 86 counties reached 78.16, which was better as a whole, but also showed some differences. Among them, the sustainable indicator of poverty alleviation governance in 47 counties exceeded the average, accounting for $54.7 \%$ of the total sample, while the sustainable indicator of poverty alleviation governance in 39 counties was lower than the average, accounting for $45.3 \%$ of the total sample. Among level 2 indicators, the average level of sustainable development indicator of poverty alleviation and governance reached 79.79. Among them, the sustainable development level indicator of poverty alleviation and governance in 40 counties exceeded the average, accounting for $46.5 \%$ of the total sample, and the sustainable development level indicator of other 46 counties was lower than the average, accounting for $53.5 \%$ of the total sample. The average indicator of sustainable development capacity for poverty alleviation and governance is 76. Among them, the sustainable development level indicator of poverty alleviation and governance in 50 counties exceeded the average, accounting for 58. In addition, the sustainable development level indicator of 36 counties was lower than the average, accounting for $41.9 \%$ of the total sample.

The study defined the counties with a score above 85 as the "Class I" of very strong sustainability, 80 to 85 as the "Class II" of relatively strong sustainability, 75 to 80 as the "Class III" of strong sustainability, 70 to 75 as the general sustainability of the "Class IV" counties, and below 70 as the weak sustainability of the "Class V" counties. Statistics show that the "first class counties" are temporarily vacant, indicating that the sustainability of poverty alleviation governance at the county level needs to be further improved. There are 26 second-class counties with strong sustainability of poverty alleviation and governance. Among them, six counties in Guangxi are in the second class, with the largest number. Helan County of Ningxia ranked first in the sustainable indicator of poverty alleviation and governance, ranking first in sustainable development ability, with an average village-level collective economic income of 426,000 yuan, and the number of village professional cooperative organizations in normal operation reached 6.1, with two higher indicators. Anhui Wangjiang County ranks first in the sustainable development level indicator, and the annual per capita net income of families in Wangjiang County is relatively high. The sustainable development ability in- 
dicator of Pinggui District of Guangxi ranks first, and the average household labor force population of Pinggui District is the largest. There are 44 "three types of counties" with strong sustainability of poverty alleviation and governance, with the largest number. There are 15 "four types of counties" with general sustainability of poverty alleviation and governance, of which 3 counties in Liaoning and 2 counties in Jilin have the lowest score of sustainable development ability indicator. One of the "five class" counties with weak sustainability of poverty alleviation and governance is the North Forest District of Heilongjiang Province (Table 5).

Poverty is an elusive, fuzzy and changing concept with uncertainty (Tan, 2012). The research focuses on poverty alleviation and governance. By carrying out practical research and data measurement, this paper discusses the construction of sustainable evaluation index system of poverty alleviation and governance, and tries to measure and evaluate the sustainable development level and sustainable development ability of provincial poverty alleviation and governance. The study found that the sustainability of poverty alleviation governance at the county level in China is good, and most counties have strong sustainability of poverty alleviation governance, with an average score of 78.2, reflecting the remarkable effect of precise poverty alleviation and precise poverty alleviation. The level 1 indicator-poverty alleviation governance sustainability indicator, the level 2 indicator-poverty alleviation governance sustainable development level indicator, poverty alleviation governance sustainable development ability indicator, the score between 75 and 80 counties are the most. This shows that most of the sample counties still have a long way to go in stabilizing poverty alleviation and promoting sustainable poverty alleviation governance. At the same time, comparing the distribution of sustainable development level indicator and sustainable development ability indicator of poverty alleviation and governance, the sustainable development level indicator is better than the sustainable development ability indicator, $9 \%$ of the counties have general or weak sustainable development level, and $33 \%$ of the counties have general or weak sustainable development ability, accounting for one-third of the sample counties. In addition, the sustainable aspect of county poverty alleviation governance in the three eastern provinces is generally weak, which needs to be focused on.

Table 5. Distribution of Level 1 Indicator and Level 2 Indicator of 486 Counties.

\begin{tabular}{ccccccc}
\hline Classification & $\begin{array}{c}\text { Distribution of } \\
\text { sustainable development } \\
\text { level indicator }\end{array}$ & $\begin{array}{c}\text { Proportion } \\
\text { of sample } \\
\text { number }\end{array}$ & $\begin{array}{c}\text { Distribution of } \\
\text { sustainable development } \\
\text { capacity indicator }\end{array}$ & $\begin{array}{c}\text { Proportion } \\
\text { of sample } \\
\text { number }\end{array}$ & $\begin{array}{c}\text { Distribution of sustainability Proportion } \\
\text { indicators for poverty } \\
\text { alleviation and governance }\end{array}$ & $\begin{array}{c}\text { of sample } \\
\text { number }\end{array}$ \\
\hline Class I & 6 & 0.07 & 1 & 0.01 & 0 & 0 \\
Class II & 34 & 0.40 & 18 & 0.21 & 26 & 0.30 \\
Class III & 38 & 0.44 & 36 & 0.42 & 0.23 & 0.51 \\
Class IV & 7 & 0.08 & 20 & 0.13 & 1 & 0.17 \\
Class V & 1 & 0.01 & 11 & & & 0.01 \\
\hline
\end{tabular}

Data source: self made by author. 


\section{Conclusion and Recommendations}

This paper studies and constructs the sustainable evaluation indicator system of poverty alleviation governance, and measures and evaluates the sustainable development level and sustainable development ability of poverty alleviation governance at the provincial level, reflecting the remarkable results of precise poverty alleviation and precise poverty alleviation, but there are still $1 / 3$ counties with insufficient sustainable development capacity worries; moreover, the sustainable aspect of county poverty alleviation governance in the three eastern provinces is generally weak, which needs to be focused on.

Its policy implication is that poverty alleviation governance will not end with the end of poverty alleviation in an all-round way. In order to consolidate the achievements of poverty alleviation in the post-poverty alleviation stage, we should start with system construction, continuously improve the system and mechanism, and enhance the endogenous development ability of poverty alleviation groups. Look specifically: First, to improve human capital, change the mental model. To consolidate the achievements of poverty alleviation, we should put the improvement of human capital in the first place and give full play to the important role of education in intergenerational transmission of poverty. The two is to ensure material capital and optimize financial capital. Third, relying on collective organizations to enhance support capital. Fourth, the system should go ahead and establish a long-term mechanism for poverty alleviation and governance. Fifth, formulate a scientific and reasonable standard of relative poverty in rural areas. Drawing lessons from the common practice of other countries in the world, it is suggested that the proportion method should be adopted to determine the national poverty line, and $40 \%$ of the median per capita disposable income of rural residents in that year should be taken as the standard of measuring relative poverty, and the poverty standard should be adjusted according to the number of children and the elderly in the family.

\section{Conflicts of Interest}

The author declares no conflicts of interest regarding the publication of this paper.

\section{References}

Alkire, S., \& Foster, J. E. (2008). Counting and Multidimensional Poverty Measurement. Journal of Public Economics, 95, 476-487.

Gao, B., \& Wang, S. P. (2014). Research on the Comprehensive Performance Evaluation System of Financial Poverty Alleviation Funds. Yunnan Social Sciences, 5, 86-89.

Ji, W. Y., \& Wu, J. B. (2018). Research on Performance Audit of Financial Poverty Alleviation Funds in Shandong Province. China Internal Audit, 9, 89-93.

Li, X. Y., \& Xu, H. Z. (2018). Some Thoughts on Poverty Alleviation Work after 2020 Journal of China National School of Administration, 2, 3-8.

Qian, L., Ni, X. F., \& Song, J. X. (2018). Multidimensional Performance Fuzzy Evaluation of Targeted Poverty Alleviation in Contiguous Poverty Stricken Areas: A Case Study of 
Dabie Mountain Area in Anhui Province. East China Economic Management, 32, 22-27.

Shi, J., \& Li, S. Q. (2018). Establishing a Scientific Effectiveness Evaluation System to Help All Kinds of Resources Targeted Poverty Alleviation-Construction of Evaluation Index System of Targeted Poverty Alleviation Effectiveness. People's Forum, 3, 36-38.

Sun, L., \& Chen, B. F. (2015). Research on Performance Evaluation of Poverty Alleviation and Development Projects Based on AHP-Tospiss Method: A Case Study of Liangshan Area in Sichuan Province. Science and Technology and Economy, 28, 62-66.

Tan, S. B. (2012). Introduction to Modern Poverty Studies. Wuhan: Hubei People's Publishing House.

Wang, X. L. (2017). Poverty Measurement: Theory and Method. Beijing: Social Sciences Academic Press.

Wang, Z. Z., \& Wang, J. (2018). Research on the Performance Evaluation of Tourism Poverty Alleviation in Minority Areas Based on Sustainable Development. Journal of Yunnan Minzu University, 35, 89-97.

Wang, Z. Z., \& Wang, L. J. (2019). Can Precision Poverty Alleviation Improve the Sustainable Livelihood of Rural Poor Households? Based on the Investigation of 70 Counties (Districts) in Shaanxi Province. Problems of Agricultural Economy, 4, 71-87.

Wang, Z. Z., Han, J. L., et al. (2018). Research on Path Optimization and Exit Mechanism of Precision Poverty Alleviation in Poverty-Stricken Areas. Beijing: People's Publishing House.

Wu, G. Q. (2017). Performance Evaluation of Poverty Alleviation and Poverty Alleviation of Tourism Industry in Poor Mountainous Areas: A Case Study of Haotang Village. Journal of Henan Normal University, 44, 63-68.

Yang, F., Chen, L. Z., Zhuang, T. H., \& Zeng, S. F. (2017). Multi-Dimensional Poverty Measurement and Spatio-Temporal Evolution of Counties from the Perspective of Sustainable Livelihoods: A Case Study of Tibetan Counties in Sichuan. Soft Science, 31, $38-42$.

Zhang, Q., \& Shi, Z. L. (2018). Construction of Performance Evaluation Index System of Education Poverty Alleviation in China. Education and Economy, 2, 35-42.

Zhang, Z. J. (2018). Performance Evaluation of Rural Tourism Targeted Poverty Alleviation in Henan Province: A Case Study of Gushi County. China Agricultural Resources and Regionalization, 39, 184-190. 